Ольга Федорівна Андрійко,

завідувач відділу проблем державного управління та адміністративного права Інституту держави і права ім. В. М. Корецького НАН України, доктор юридичних наук, професор, член-кореспондент НАПрН України

\title{
ПРАВОВИЙ МОНІТОРИНГ В СИСТЕМІ ОРГАНІВ ВИКОНАВЧОЇ ВЛАДИ
}

Системність відстеження, аналіз та об'єктивна оцінка діяльності органів виконавчої влади, прогнозування викликів та своєчасне попередження ризиків, що можуть мати місце, в значній мірі позитивно впливати на ефективність діяльності усієї системи органів виконавчої влади. Завданням реформування іiї $є$ створення прозорої, відкритої та гнучкої структури системи, діяльність якої спрямована на суспільний сталий розвиток та адекватне реагування на виклики, вчасне виявлення яких та належне регулювання і є одним із завдань моніторингу.

Постановка проблеми. Правовий моніторинг на сьогодні $€$ ще недостатньо вивченим у науці явищем, зокрема, що стосується його взаємозв'язку з такими видами діяльності, як контроль і нагляд, та визначенням його ролі у підвищенні ефективності діяльності системи органів виконавчої влади та кожного з органів, зокрема. Проте в умовах децентралізації влади, реформування системи органів виконавчої влади та перерозподілу їх повноважень, широкому використанні інтегрованої інформаційної та комунікаційної техніки надзвичайно важливим $€$ постійний моніторинг діяльності усієї вертикалі виконавчої влади, а отже, його наукове осмислення.

Аналіз останніх досліджень і публікацій. Зазвичай питанням моніторингу хоч і приділялася певна увага у наукових публікаціях, однак вони не були предметом детального аналізу. У більшості 3 них увага була в основному приділена проблемам контролю у сфері державного управління і лише окремі посилання на його різноманітні форми, зокрема, у роботах таких авторів, як: В. М. Гаращук, О. Ф. Андрійко, О. І. Сущинський, С. С. Вітвітський, А. К. Денисова та ін.

Мета статті - розглянути сутність, природу та функції явища «правовий моніторинг» та його зв'язок із іншими формами контрою.

Основні результати дослідження. Проведений аналіз наукової літератури дає можливість стверджувати, що на сьогодні дослідження такого явища, як «правовий моніторинг», в системі органів виконавчої влади ще не має завершеного вигляду як у своєму термінологічному визначенні, так і змістовному наповненні. За тим маємо певну кількість підходів до визначення поняття моніторингу, якими в залежності від ситуацій, врахування різних чинників і оперують автори досліджень як самого явища, так і в контексті з іншими, в залежності від конкретної мети.

У літературі зазначається, що контроль $є$ родовим поняттям відносно таких термінів, як нагляд, аудит, моніторинг, контролінг, ревізія, перевірка тощо [1, с. 28].

У Великому енциклопедичному юридичному словнику при визначенні терміна «моніторинг» щодо різних об'єктів (земель, навколишнього природного середовища) вказується на те, що він являє собою систему спостережень за станом відповідних об'єктів з метою своєчасного виявлення змін, їх оцінки, відвернення та ліквідації наслідків негативних процесів [2, с. 484]. Юридична енциклопедія дає визначення моніторингу в англійській мові як контроль; а в латинській «monitor» - той, хто попереджає, застерігає, радник, консультант - регулярне спостереження за станом природних, технічних і соціальних процесів з метою їх оцінки, контролю та прогнозування. Порядок проведення моніторингу регулюється відповідними правилами. Інформація, отримана за допомогою моніторингу, кладеться в основу рішень, що приймаються державними органами, політичними партіями, громадськими організаціями [3, с. 764].

У затвердженому постановою Кабінету Міністрів України від 21 грудня 2016 р. № 990 Порядку здійснення контролю у сфері державної реєстрації термін «моніторинг реєстраційних дій» визначається як комплекс організаційних та технічних заходів, які забезпечують систематичну, вибіркову перевірку дотримання державними реєстраторами прав на нерухоме майно, державними реєстра- 
торами юридичних осіб, фізичних осіб - підприємців та громадських формувань, уповноваженими особами суб'єктів державної реєстрації законодавства під час проведення реєстраційних дій. Контроль за діяльністю у сфері державної реєстрації здійснюється шляхом розгляду скарг, поданих відповідно до Закону України «Про звернення громадян», і обгрунтованих подань територіальних органів Мін'юсту, а також моніторингу реєстраційних дій в реєстрах.

Моніторинг реєстраційних дій проводиться на підставі відомості реєстрів за такими критеріями:

1) порушення строків, визначених Законами;

2) проведення реєстраційних дій в неробочий час;

3) відсутність у реєстрах електронних копій документів, поданих для державної реєстрації, виготовлених шляхом їх сканування;

4) проведення реєстраційних дій на підставі судових рішень;

5) скасування (видалення) записів з реєстрів;

6) державні реєстратори та/або суб'єкти державної реєстрації, визначені Мін'юстом.

В Основних засадах здійснення внутрішнього контролю розпорядниками бюджетних коштів та внесення змін до постанови Кабінету Міністрів України від 28 вересня 2011p. № 1001, затвердженої постановою Кабінету Міністрів України від 12 грудня 2018 р. № 1062, моніторинг визначається як один із елементів системи внутрішнього контролю, полягає у відстеженні стану організації та функціонування системи внутрішнього контролю в цілому та/або окремим його елементом. Зазначається, що елементи внутрішнього контролю взаємопов'язані і стосуються всієї діяльності.

Внутрішніми документами установи, як зазначається в Основних засадах, повинно бути врегульовано і здійснення моніторингу. Зокрема, йдеться про:

- здійснення постійного моніторингу під час поточної діяльності установи (управлінські та наглядові заходи керівників та працівників установи під час виконання ними своїх обов'язків для визначення та коригування відхилень);

- проведення періодичної оцінки виконання окремих завдань та функцій (зокрема працівниками, які не несуть відповідальності за їх виконання, та/або підрозділом внутрішнього аудиту установи) для проведення аналізу результативності системи внутрішнього контролю;

- інформування керівництва установи щодо недоліків у системі внутрішнього контролю, виявлених за результатами здійснення моніторингу.

Запроваджений в установі моніторинг повинен забезпечувати виявлення та оцінку відхилень у функціонуванні системи внутрішнього контролю та/або окремих його елементів та вжиття заходів для усунення таких відхилень.

Отже, маємо приклад врегулювання проведення моніторингу внутрішніми документами у відповідних установах.

В останні роки така форма контролю, як моніторинг, набуває поширення як в системі органів виконавчої влади, так і при виконанні різних проектів, програм, окремих завдань. За наслідками впливу його можна віднести умовно до «м'якої» форми контролю, оскільки суб'єкт, що проводить моніторинг, в основному обмежується інформуванням про виявлені відхилення в діяльності системи та аналізом наслідків, їх констатацією. Застосування моніторингу пов'язується з відстеженням ситуації чи процесу, у сфері управлінської діяльності, зокрема, аналізом впливу на суспільні відносини прийнятих управлінських рішень, правових актів. При цьому застосовуються такі «безконтактні» способи і прийоми моніторингу як аналіз стану, співставлення із поставленими завданнями, що здійснюються за допомогою спостережень, оцінок, за допомогою різних технічних засобів тощо. Результати моніторингу стають предметом обговорення та прийняття рішення на рівні уповноваженого суб'єкта [4, с. 347]. Аналіз понятійно-категоріального апарату моніторингу, в науковій літературі, положень законодавства дає можливість виокремити його основні ознаки. До них слід віднести: 1) це одна із форм контролю; 2) системність проведення; 3) здійснення шляхом спостереження, аналізу, перевірки, співставлення та оцінки стану; 4) метою $є$ отримання достовірної інформації про стан об'єкта; 5) об'єктами моніторингу в системі органів виконавчої влади $є$ стан проведення державної політики у відповідних галузях, чинне законодавство, проекти нормативно-правових актів.

Основними функціями моніторингу є аналітично-інформаційна, яка дає можливість відстежувати стан виконання поставлених завдань, виконання їх в установлених межах та спрямування на досягнення визначених результатів, відстеження процесу реалізації управлінських рішень: ко- 
ординуюча - спрямована на координацію дій суб'єктів в системі управління, в процесі підготовки i прийняття рішення; організаційна функція моніторингу дає можливість за допомогою організаційних заходів переформатувати підходи, форми та способи здійснення поставлених завдань; прогностична - спрямована на вироблення управлінських рішень в контексті врахування ситуативних факторів.

У монографічній роботі, підготовленій групою науковців за результатами дослідження сучасних тенденцій організації діяльності органів виконавчої влади таких країн, як Велика Британія, США, Франція, Німеччина, Нідерланди, Норвегія та Японія, було виділено чотири основні форми контролю над органами виконавчої влади. Однією із них став нагляд, який «працює внаслідок моніторингу та управління індивідами згори» [5, с. 16]. При виділенні видів наглядових інспекцій в органах влади та державної служби (а їх визначають щонайменше сім різних видів) дослідники вказують: «П'ятий вид становлять власні органи моніторингу та визначення стандартів у самій структурі виконавчої влади...». При цьому зазначають, що «складова структура основних форм контролю дає змогу аналізувати засоби контролю в будь-який час у різних сферах політики та країнах, порівняно незалежно від інституцій і без огляду на припущення стосовно контролю, зумовлені якою-небудь однією державною традицією» [6, с. 20].

У заяві, зробленій Міністерством освіти і науки України в засобах інформації, йдеться про наміри створення системи моніторингу працевлаштування випускників вузів і профтехнікумів. Це дозволить, як зазначається у заяві, відстежувати успішність подальшої кар'єри випускників у прив' язці до вузу, який вони закінчили, та аналізувати перспективи університетів. На основі отриманих даних міністерство оцінить якість навчання у вузі і вдосконалить свою політику щодо них. Результати моніторингу будуть корисні і абітурієнтам, які зможуть обирати вуз з огляду на успішність його випускників [7].

Отже, наведені приклади дають сподівання, що моніторинг поступово займає належне місце в системі контролю, як «м'яка» його форма, мета якої є спостереження за процесами діяльності адміністративних структур, та здійснення коригуючих заходів, за відповідністю ії законодавству.

У Стратегії реформування державного управління України на 2016-2020 роки, схваленої розпорядженням Кабінету Міністрів України від 24 червня 2016 року № 474-р, зазначається, що система стратегічного планування, моніторингу та аналізу передбачає наявність системи взаємопов'язаних і взаємоузгоджених програмних і стратегічних документів державної політики. За станом реалізації стратегій здійснюватиметься моніторинг і регулярне звітування.

Розпорядженням Кабінету Міністрів України від 27 грудня 2017 р. № 1013-з було схвалено Концепцію оптимізації системи центральних органів виконавчої влади. У Розділі II «Проблеми, які потребують розв’язання», зокрема, зазначається, що «у міністерствах фактично відсутня якісна система моніторингу (контролю) та оцінювання реалізації державної політики, що не дає змоги у разі потреби корегувати відповідну політику чи обрані інструменти для їі впровадження». «Робота в міністерстві в основному зосереджуватиметься на стратегічному плануванні, забезпеченні формування державної політики, здійснення моніторингу (контролю)та оцінювання результатів їх реалізації». Отже, йдеться про моніторинг як форму контролю за реалізацією державної політики, що у разі потреби дасть можливість корегувати ії за допомогою інструментів впливу. У даному контексті терміни «моніторинг» і «контроль» вживаються як взаємозамінні.

У Законі України «Про запобігання корупції» у підпункті 2 пункту 1 статті 11 до повноважень Національного агентства визначено «розроблення проектів Антикорупційної стратегії та державної програми з їі виконання, здійснення моніторингу, координації та оцінки ефективності виконання Антикорупційної стратегії. А в підпункті 6 пункту 1 цієї статті до повноважень віднесено «здійснення моніторингу та контролю за виконанням актів законодавства 3 питань етичної поведінки, запобігання та врегулювання конфліктів інтересів у діяльності осіб, уповноважених на виконання функцій держави або місцевого самоврядування». Виокремлення моніторингу підкреслює важливість, значимість та самостійність його при аналізі дотримання чинного законодавства відповідними суб'єктами, але вже як самостійного явища.

У всіх цих повноваженнях Національного агентства щодо проведення моніторингу йдеться про відстеження дій, аналізу діяльності. Тоді як у підпункті 81 зазначається, що державний контроль здійснюється у порядку та в межах визначених законом за дотриманням встановлених законом обмежень щодо фінансування політичних партій, законним та цільовим використанням політичними 
партіями коштів, виділених з державного бюджету на фінансування їхньої статутної діяльності, своєчасністю подання звітів партій про майно, доходи, витрати і зобов'язання фінансового характеpy, звітів про надходження і використання коштів виборчих фондів на загальних та місцевих виборах, повнотою таких звітів, звіту зовнішнього незалежного фінансового аудиту діяльності партій, відповідністю їх оформлення встановленим вимогам, достовірністю включених до них відомостей.

Отже, йдеться про контроль не як спостереження за діяльністю, а як контроль за відповідністю iі закону.

Аналіз наукової літератури, офіційних матеріалів та законодавства засвідчує існування різних підходів щодо визначення моніторингу та його співвідношення із такими термінами, як «контроль» i «нагляд». Можна виділити два основних підходи, що прослідковуються - це коли моніторинг розглядається як самостійне явище, при здійсненні якого чітко виділяється його мета, спосіб та наслідки, і другий підхід, за яким моніторинг є однією із форм контролю.

Висновки. Підсумовуючи результати проведеного дослідження, слід зазначити, що проведений аналіз наукової літератури, стратегічних напрямів реформування державного управління в Україні та чинного законодавства засвідчив значну увагу до правого моніторингу та удосконалення таких його складових, як аналітичність, інформаційний характер, прогностичність, які дають можливість безконтактно відстежувати стан об'єкта та вчасно передбачати можливі ризики. У зв'язку з цим проблема подальшого дослідження застосування моніторингу та його правової визначеності в діяльності органів виконавчої влади має бути в полі зору науковців та практиків.

\section{Список використаних джерел}

1. Шестак C. В. Недержавний контроль за діяльністю міліції: теоретико-правовий аспект: дис. ... канд. юрид. наук: 12.00.01. Харків, 2009 с. 199 с.

2. Великий енциклопедичний юридичний словник / за ред. академіка НАН України Ю. С. Шемшученка. Київ: Вид-во «Юридична думка», 2007.

3. Юридична енциклопедія: в 6 т. / редкол.: Ю. С. Шемшученко (голова) та ін. Київ: Вид-во «Українська енциклопедія» ім. М. П. Бажана. 2001. Т. 3: К-М. 792 с.

4. Державне управління: проблеми адміністративно-правової теорії та практики / за заг. ред. В. Б. Авер'янова. Київ: Факт, 2003.

5. Контроль в органах виконавчої влади в сучасних умовах. Розмаїття, спільні риси та зміни / упоряд.: Кристофер Гуд, коледж «All Souls», Оксфорд, Велика Британія; Олівер Джеймс, Екзетерський університет, Велика Британія; Б. Гай Пітерс, Пітсбурський університет, США; Колін Скот, Лондонська школа економіки та політології, Велика Британія. Київ: Вид-во «К. І. С.», 2006.

6. Там само.

7. Успешность вузов оценят. Сегодня: газета. 2019. № 102 (5945).

\section{Андрійко О. Ф. Правовий моніторинг в системі органів виконавчої влади}

У статті зосереджено увагу на сутності, понятті та значенні моніторингу щодо діяльності органів виконавчої влади та їх відносин з іншими суб'єктами. Дослідження зосереджено на основних ознаках моніторингу, що відрізняють і поєднують його з контролем і наглядом, функціях та проявах стосовно відповідних суб'єктів, діяльність яких відстежується, аналізується та удосконалюється. Обгрунтовується необхідність розширення прогностичної функції моніторингу щодо ефективності нормативно-правових актів у сфері виконавчої влади.

Ключові слова: правовий моніторинг, основні ознаки та функції моніторингу, контроль, нагляд, органи виконавчої влади.

\section{Andriiko O. F. Legal monitoring in the system of executive authorities}

The system of observing, analysis and objective assessment of executive bodies' activity, forecasting challenges and timely preventing risks that may happen have a significant positive effect on the efficiency of the system of executive authorities. The objective of reform is to create a transparent, open and flexible system, whose activities aim at social sustainable development and adequate response to challenges.

An important role in the implementation of the task and the further effective functioning of the system and its authorities is monitoring, one of the forms of control that has become widespread in recent years. In the academic literature monitoring in the system of executive authorities remains an insufficiently researched phenomenon, and its main features and functions have not been sufficiently substantiated and accented. It is possible to state that the problem of monitoring, although given some attention in the academic publications, while its role in public administration, features and functions were not the subject of extensive researches. 
In the process of the research, the author has come to the conclusion that the main features of monitoring as the form of control are the systematic of implementation; noninterference in the direct activity of the subject; implementation through observation, analysis, prevention, etc.

The objects of monitoring in the system of executive authorities are activity in accordance with the tasks, regulations, implementation of legal orders. Among the main functions should accent analytical and informative, preventive, coordinative, organizational and prognostic functions.

The analysis of academic literature, strategic directions of the reform of public administration in Ukraine and current legislation has shown significant attention to the legal monitoring and improvement of analytical and informational components, which give possibility to make contactless monitoring of the conditions of the object and timely predict possible risks. In this regard, the problem of further improving the implementation of monitoring of the executive authorities' activities and its legal support should be in the spotlight of scientists and practitioners.

Key words: legal monitoring, main features and functions of monitoring, control, supervision of executive authorities.

DOI: 10.33.66.3/2524-017X-2019-10-27-31

УДК 340.1

Б. І. Андрусииин,

професор кафедри теорії та історії держави і права Національного педагогічного університету імені М. П. Драгоманова, доктор історичних наук, професор, заслужений діяч науки і техніки Украӥни

\section{МІЖНАРОДНИЙ КОНТРОЛЬ ЯК «НЕВІДКЛАДНА ІНСТИТУЦІЯ» ВДОСКОНАЛЕННЯ УПРАВЛІННЯ ДЕРЖАВОЮ}

Постановка проблеми. Зовнішня політика України спрямовується на утвердження й розвиток нашої країни як незалежної демократичної держави, на збереження ії територіальної цілісності та недоторканності кордонів, на включення національного господарства у світову економічну систему, на поширення в світі образу України як надійного і передбачуваного партнера. Діяльність сучасної Української держави у сфері міжнародного співробітництва базується на дотриманні міжнародних стандартів прав людини, принципу неподільності міжнародного миру і міжнародної безпеки, визнанні пріоритету загальнолюдських цінностей, пріоритеті норм міжнародного права перед нормами внутрішньодержавного права, засудженні практики подвійних стандартів у міждержавних стосунках тощо.

Особливе місце у процесі співробітництва держав належить міжнародному контролю, який здійснюється на основі договору про взаємодію між суб'єктами міжнародного права в тій чи іншій сфері міжнародних відносин і являє собою обумовлені сторонами заходи перевірки виконання взятих ними зобов'язань. Такі заходи здійснюються за допомогою діяльності контрольних органів, які створюються на базі міжнародних органів та організацій. Зобов'язання, що стосуються реалізації контролю на міждержавному рівні, випливають із міжнародного договору, що грунтується на засадах добровільності, взаємності, неприпустимості втручання у внутрішні справи один одного, узгодженні міжнародного і національного права.

Міжнародний контроль покликаний підтримувати врегульовані договором відносини з приводу певних дій або утримання від них, зберігати встановлений стан речей у межах узгодженого сторонами правового режиму. За допомогою міжнародного контролю здійснюється констатація виконання міжнародно-правового зобов'язання або відходу від нього. В останньому випадку держава-учасник договору зобов’язана усунути ситуацію, яка загрожує виконанню договору, та вжити заходів щодо його неухильного дотримання.

Аналіз останніх досліджень та публікацій. Свого часу питання щодо міжнародного контролю як дієвого інструмента вдосконалення управління державою досліджувалися у працях П. Алстона, Є. Бредлі, Б. Бутрос-Галі, Т. Буєргенталя, Н. Вальтікоса, К. Вассека, Д. Гом’єн, М. Дженіса, Л. Зваака, І. Камерона, А. Кассезе, Р. Кея, Г. Лаутерпахта, С. Лекі, Д. МакГолдріка, Р. Норіса, Б. Рамчарана, А. Робертсона, Х. Саба, П. Сіджхарта, М. Тарді, Д. Харріса, У.А. Шабота, Д. Шелтона та ін. 